Provided for non-commercial research and education use. Not for reproduction, distribution or commercial use.

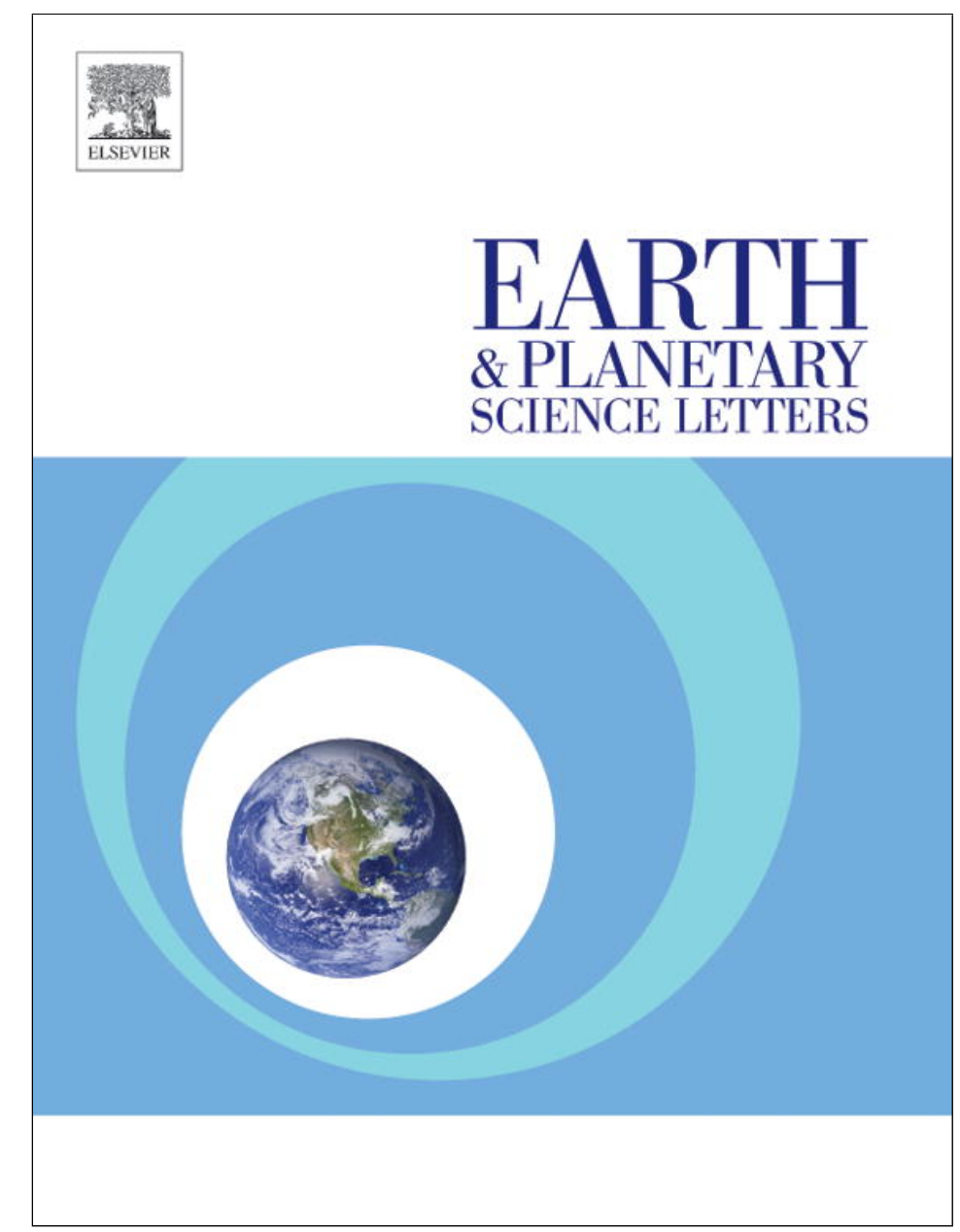

(This is a sample cover image for this issue. The actual cover is not yet available at this time.)

This article appeared in a journal published by Elsevier. The attached copy is furnished to the author for internal non-commercial research and education use, including for instruction at the authors institution and sharing with colleagues.

Other uses, including reproduction and distribution, or selling or licensing copies, or posting to personal, institutional or third party websites are prohibited.

In most cases authors are permitted to post their version of the article (e.g. in Word or Tex form) to their personal website or institutional repository. Authors requiring further information regarding Elsevier's archiving and manuscript policies are encouraged to visit:

http://www.elsevier.com/copyright 


\title{
Fault rock injections record paleo-earthquakes
}

\author{
Christie D. Rowe*, James D. Kirkpatrick, Emily E. Brodsky \\ Earth and Planetary Sciences, University of California Santa Cruz, 1156 High St, Santa Cruz, CA 95064, United States
}

\section{A R T I C L E I N F O}

\section{Article history:}

Received 8 November 2011

Received in revised form

8 April 2012

Accepted 9 April 2012

Editor: P. Shearer

\section{Keywords:}

pseudotachylyte

overpressure

gouge

injection veins

dynamic weakening

thermal pressurization

\section{Introduction}

Once earthquake slip has initiated, weakening of the fault plane is necessary to accelerate slip and propagate the earthquake rupture. Transient high fluid pressure in faults is often proposed as a potential co-seismic fault weakening mechanism. High pressures may be created in situ during seismic slip by a sudden change in fault rock or fluid volume or density, driven by frictional heating on the rupture surface causing thermal expansion or phase change. Numerical models have been used to explore the degree of overpressure necessary to promote earthquake slip (Wibberly, 2002; Brantut et al., 2010; Mitsui and Hirahara, 2010), and previous studies have measured pore pressure changes in high velocity slip experiments on fault gouges which are attributable to thermal expansion of pore fluids (Ferri et al., 2010; Tanikawa and Shimamoto, 2009). However, no direct measurements of in situ overpressure in a fault during seismic slip have been reported so the degree of pressurization and importance for coseismic processes remains unknown.

\footnotetext{
* Corresponding author. Now at Earth and Planetary Sciences, McGill University, 3450 University St., Montréal, QC, Canada H3A 2A7. Tel.: +1 514 389-2769.

E-mail address: christie.rowe@mcgill.ca (C.D. Rowe).
}

In igneous systems, melt overpressure can be constrained by the shape of dikes. The aspect ratio of a dike records the shear strain of the fracture, related to the driving pressure in the melt. An elastic opening-mode crack has an aspect ratio that is approximately the ratio of the overpressure to the shear modulus (Rubin, 1995). In other words, the strain recorded in the rock record is controlled by the net pressure required to open the crack. At most scales, aspect ratios from $10^{-4}$ to $10^{-3}$ are common (Rubin, 1995; Gudmundsson, 1995; Cruden and McCaffrey, 2006).

Faults can also have injection features that resemble miniature dikes. Perhaps the clearest examples are pseudotachylyte injection veins. Pseudotachylyte forms from co-seismic frictional melting along an earthquake slip surface (Philpotts, 1964; Sibson, 1975). Injection veins emanating from the fault surfaces are common in pseudotachylyte-bearing faults (e.g. Passchier, 1982; Macaudiere et al., 1985; Swanson, 1989). The width/height ratio of an injection vein preserves the strain in the wall rock around the fluid-filled crack, in an analogous way to dikes. These small melt bodies quench within $\sim 1-100 \mathrm{~s}$ (Dixon and Dixon, 1989), so the solidification of the melt occurs within the coseismic to immediately post-seismic period and records conditions at that time.

Injections of clastic fault rock (gouge, cataclasite and breccia) are also well-known (e.g. Cowan et al., 2003), and are sometimes suggested to have formed during earthquake slip (Ujiie et al., 2007; 
Rowe et al., 2005; Lin, 2011). The duration of flow of granular fault rocks is not well-constrained (Cowan, 1999). Gas-phase granular flow (sensu Jaeger and Nagel, 1996) requires high particle velocities, and may leave a distinct textural signature (Otsuki et al., 2003). However, there is no broadly accepted evidence to distinguish signatures of coseismic deformation from static granular flow.

In this paper, we use the injection features along faults to infer the overpressure in the fault zone. We measure pseudotachylyte injection veins from the Asbestos Mountain fault, California, and clastic injections from the Naukluft Thrust, Namibia, the Badwater Detachment, California, and the Muddy Mountain Thrust, Nevada. We examine predicted coseismic pressurization along the faults and interpret the aspect ratios of the injections, which indicate higher pressures, as representative of co-seismic stress conditions.

\section{Geologic setting: pseudotachylyte faults}

The pseudotachylyte-bearing Asbestos Mountain fault crops out in the wall of Deep Canyon, south of Palm Desert, California
(Fig. 1) (Sharp, 1979; Simpson, 1984; Wenk et al., 2000). It is one of the system of gently eastward-dipping $\left(20-30^{\circ}\right)$ faults recognized in the Santa Rosa Mountains that are spatially associated with, but structurally higher than, the Santa Rosa segment of the eastern Peninsular Ranges mylonite zone (Sharp, 1968, 1979; Todd et al., 1988; Simpson, 1984). The faults likely initiated as thrusts associated with Laramide contraction, then reactivated during late Miocene extension (Axen and Fletcher, 1998; George and Dokka, 1994; Erskine and Wenk, 1985). In spite of the complex tectonic history, the latest brittle phase of deformation is well-defined by field observations. The generalized fault zone stratigraphy at Deep Canyon is shown in Fig. 1. Pseudotachylytes are most abundant in the hanging wall of the fault, which juxtaposes Cretaceous plutons (tonalite to granodiorite of the Asbestos Mountain suite) and amphibolite-facies supracrustal rocks (Palm Canyon Metamorphic Complex).

The fault is defined by a 11-18 $\mathrm{m}$ damage zone in the hanging wall, a 5-10 m fault core containing both hanging wall and foot wall-derived material, and a foot wall damage zone of epidote alteration $\sim 30 \mathrm{~m}$ thick (Fig. 1 ). The fault core is a thoroughly

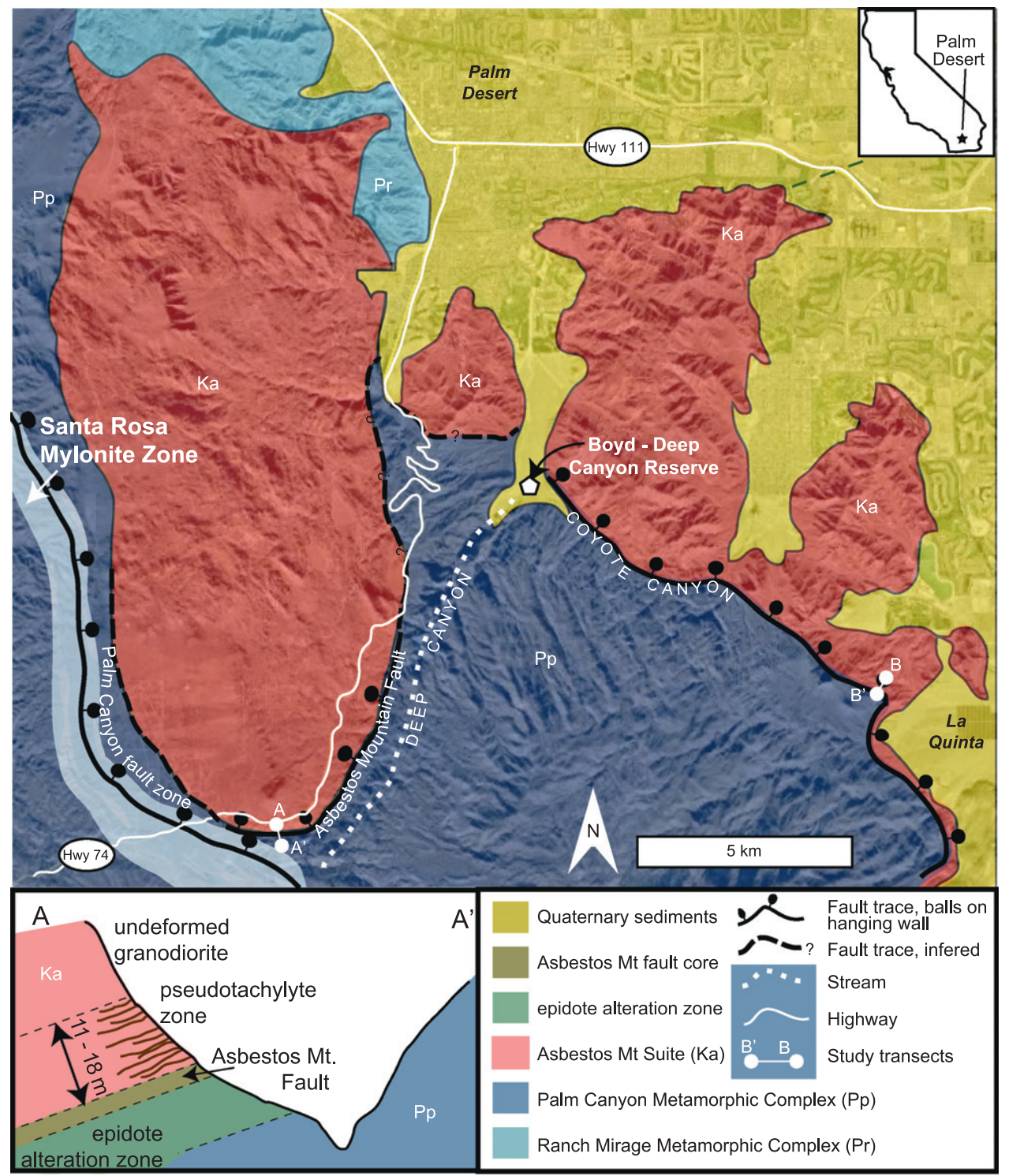

Fig. 1. Study location near Palm Desert, California. Base image from Google Earth. Geology modified from Sharp (1979), Todd et al. (1988) and Wenk et al. (2000). Sense of motion of the fault has complex history - circles indicate hanging wall. Transect A-A' shows location of inset schematic cross section through fault zone exposure below Hwy 74 in Deep Canyon. Pseudotachylyte-bearing zone in hanging wall is 11-18 m thick at study site. Epidote alteration zone in footwall is highly variable in thickness along strike. Transect B indicates location of pseudotachylyte vein density transect through probable along-strike equivalent fault zone. 
altered, epidote-bearing zone of brecciated rock with no pseudotachylyte veins. The hanging wall damage zone is characterized by a wavy foliation in the granodiorite, which is offset by discrete ductile shears less than $1 \mathrm{~cm}$ thick (Fig. 2D). These are commonly epidotized. Alkali feldspar-rich pegmatitic veins crosscut the ductile fabrics and are associated with the epidote alteration (Fig. 2E). In the hanging wall, fault-parallel pseudotachylyte veins from $\sim 1 \mathrm{~mm}$ to $1 \mathrm{~cm}$ thick occur in concentrated zones $3-5 \mathrm{~m}$ thick (Fig. 1, inset), and crosscut both the ductile fabrics and the pegmatitic veins (Fig. 2). Although slope stability and scree cover prevented a quantitative transect at this locality, a measured transect through a possible along-strike equivalent outcrop at La Quinta gave an average pseudotachylyte vein density of $1.4 / \mathrm{m}$, in agreement with previous workers (Wenk et al., 2000) (Fig. 1; transect B).
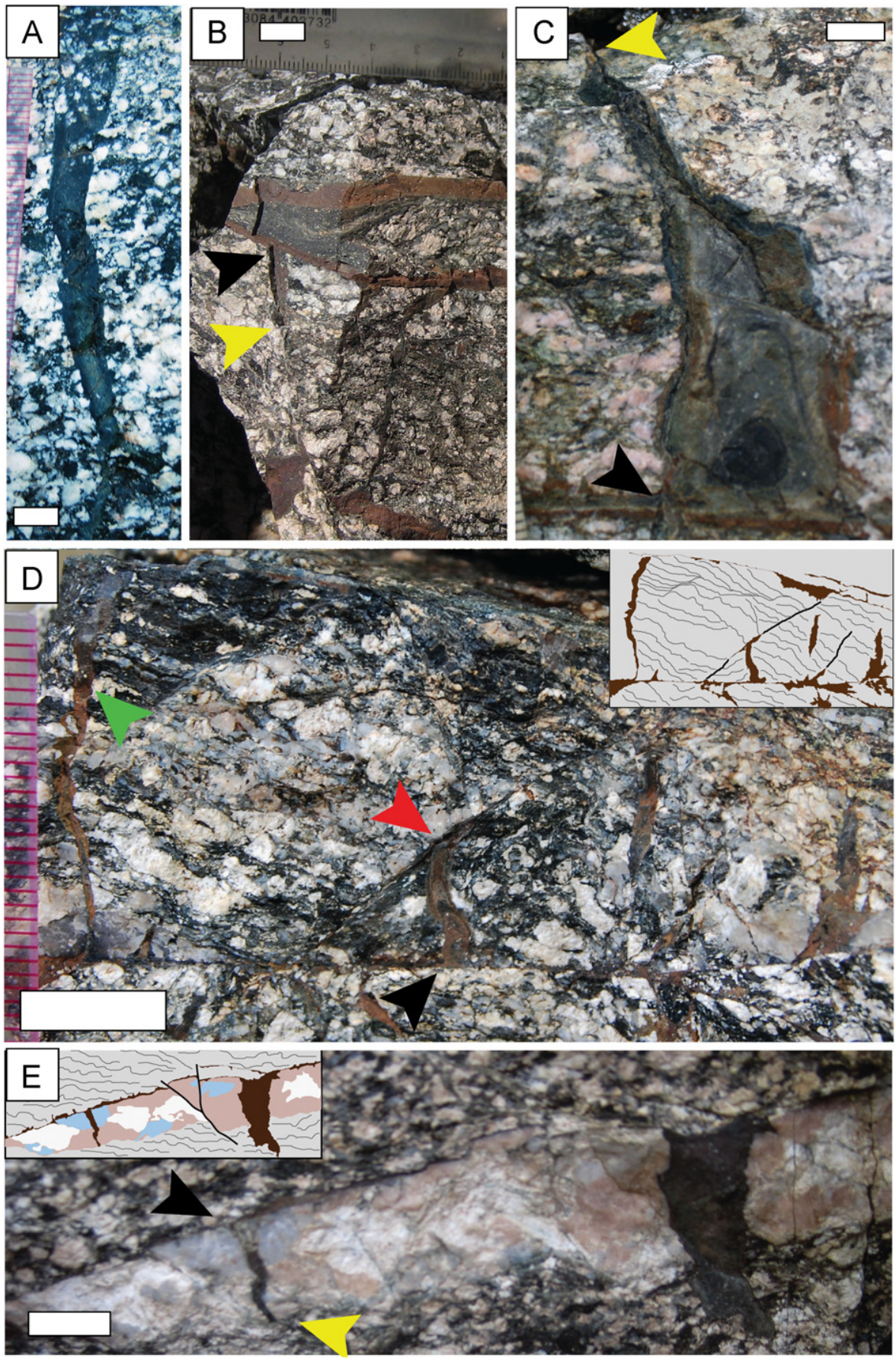

Fig. 2. Pseudotachylyte injection vein features. Scale bars are $1 \mathrm{~cm}$. Black arrows show continuity between source fault vein and injection. Yellow arrows show injection tips (natural terminations). Red arrow shows where an injection is deflected along a subsidiary shear. Green arrow shows an injection vein which connects two fault veins. (A) Clasts of feldspar in the opening of a pseudotachylyte injection vein; (B) two sub-parallel fault veins, exposed in 3D on outcrop corner, with three downward injections emanating from lower vein. Erosion of injection vein edges enabled field measurement of the strike and dip of each vein. (C) Slightly oblique view of wide pseudotachylyte injection vein shows $\approx 2 \mathrm{~mm}$-wide quenched margin and concentric cooling bands; (D) high density region of small injection veins between two small faults. Fault veins are locally less than $1 \mathrm{~mm}$ thick, demonstrating draining of melt from faults into injection veins. Inset interpreted sketch shows pseudotachylyte fault and injection veins (brown), subsidiary faults which do not contain pseudotachylyte (black) and pre-existing wall rock fabric (gray). (E) Pseudotachylyte-bearing fault running along edge of pegmatite vein that cuts the pre-existing ductile fabric in the granodiorite. Interpreted sketch: Pegmatite vein: pink, white and blue represent alkali feldspar, plagioclase feldspar and quartz, respectively. Pseudotachylyte fault and injection veins are brown. Pre-existing fabric shown in gray. 
The pseudotachylyte fault veins are commonly $\sim 5-10 \mathrm{~mm}$ thick, but are much thinner in areas where off-fault injection veins are abundant (compare Fig. 2B vs. D). This reflects the draining of frictional melt from the fault into off-fault cracks. Injection veins extend both upward and downward from the slip surface and are often thicker than the fault veins. Rarely, survivor grains within the pseudotachylyte melt may clog the aperture of an injection vein (Fig. 2A), but in general the melt contains few survivor grains and the grains are isolated and much smaller than the vein aperture. Some injection veins have quenched margins and concentric cooling textures (Fig. 2C), showing that the melt was static during cooling.

\section{Field methods}

We measured pseudotachylyte injection vein and granular injection vein widths and heights. We re-visited the pseudotachylytes in the Asbestos Mountain fault zone, California, described by Wenk et al. (2000). Our observations of granular injections are from several faults in different tectonic settings. Following convention, we will describe the pseudotachylyte layers in fault-parallel slip surfaces as "fault veins". Pseudotachylytes occupying cracks which branch from slip surfaces at high angles, showing little or no shear displacement, are referred to as “injection veins" (Sibson, 1975; Grocott, 1981; Swanson, 1992). Fault veins lie in the slip surface where they were generated; injection veins lie in cracks where no melt was formed and are completely filled from connected fault veins.

We selected injections to measure whose geometry is consistent with simple elastic cracks by using the following criteria for every vein: (1) We observed a continuous connection between the pseudotachylyte fault vein and the injection vein or the fault core containing fault gouge and the granular injection vein (black arrowheads, Fig. 2); (2) We observed the tip of the injection where the injection vein thickness decreased to zero, whether or not a fracture continued beyond the injected material (yellow arrowheads, Fig. 2); (3) We rejected veins that appeared to follow foliation in the host rock or that turned sharply into foliation or fractures which they intersected, indicating an influence of wall rock heterogeneities (red arrowhead, Fig. 2D); (4) As pseudotachylytes often have interconnected geometries (e.g. Sibson, 1975), we rejected pseudotachylyte veins that connected two fault veins (green arrowhead, Fig. 2D), were part of a network of veins, or formed breccias; (5) Veins that contained individual clasts with diameters approximately the same size as the width at any point in the injection, or those with a group of clasts spanning the width of the vein (Fig. 2A) were rejected to eliminate cases where the walls of the injection were propped open, (6) Injections of the same scale as individual grains of the host rock were rejected, as these may represent grain plucking or preferential melting rather than crack-filling (Fig. 3A,B).

The following features, where present, added confidence to our selection of veins: (7) We observed only opening-mode offset of individual grains across the injection (e.g. Fig. 2E) demonstrating that the melt did not intrude along a subsidiary slip surface; (8) concentric zoning within individual injections demonstrated a single phase of injection and melt quenching, eliminating the possibility of multiple phase growth (e.g. Fig. 2C).

We measured the heights and widths in the field and from scaled photographs (Fig. 3B). The width of the injection veins was measured at the base of the injection where it branches from the fault vein or fault core. Heights were defined as the distance from the branching point to the tip of the injection where the thickness diminished to zero. Many injection veins show a slight waviness, but the height was measured in a straight line from the center of the base of the injection vein to the tip. The difference between our height measurements and the curved line through the center
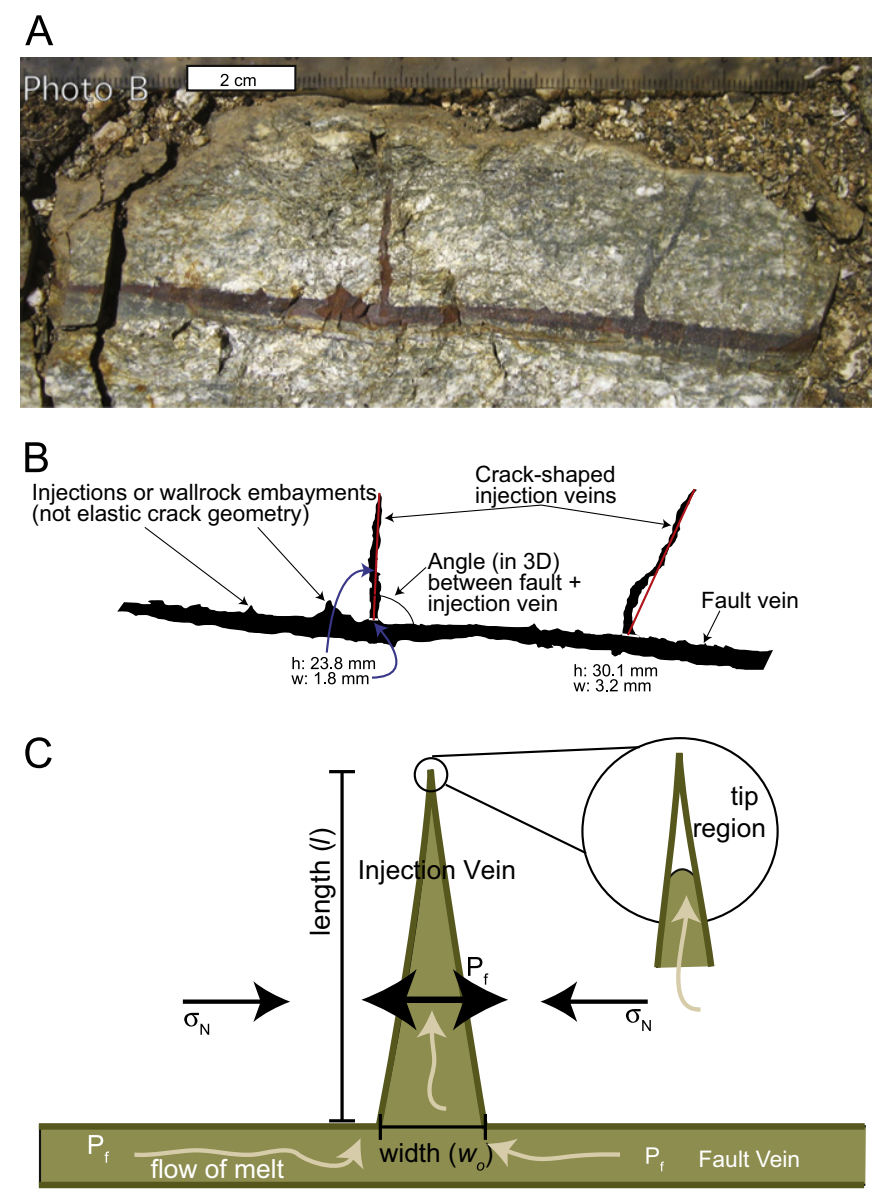

Fig. 3. A, Pseudotachylyte injection veins and idealized geometry of melt-filled cracks. Field photo of pseudotachylyte fault vein with multiple upward injections, illustrating the two geometries of grain-scale, low aspect ratio injections, and crack-shaped, high aspect ratio injections. Fault vein is sharp and planar on both edges. B, Diagram of the photo shows the location of measurements: white arrows are the measured width of the injection; red arrows show the measured height. For all adequately exposed injection veins, the strike and dip of both fault vein and injection veins were measured in the field and the angle between the planes was calculated using a stereonet. $C$, simplified geometry of injection vein. Tan arrows show direction of melt flow during injection. $P_{f}$ indicates direction fluid pressure acting to open the injection vein. $\sigma_{N}$ indicates direction of normal stress in wall rock acting to close injection vein. Inset shows tip of injection vein where crack opening precedes flow of pseudotachylyte melt. See text for discussion. (For interpretation of the references to color in this figure caption, the reader is referred to the web version of this article.)

of the injection is not more than $5 \%$ and does not affect the conclusions of this work.

The weathered outcrop along the wall of Deep Canyon often enables three-dimensional observations of pseudotachylyte fault veins and injection veins sourced from them in the Asbestos Mountain fault zone (Fig. 2B). We measured the orientation of injection veins and the local fault vein where possible, and later calculated the angle between the fault and injection planes.

\section{Pseudotachylyte injection vein aspect ratios and orientations}

Pseudotachylyte injections form in a variety of sizes (Figs. 2 and 3A). Due to the grain size of the host rock, injections meeting our criteria are at least a few millimeters tall. At smaller scales, an additional group of injections is observed. They are usually less than $5 \mathrm{~mm}$ in height (Fig. 3A, B). These features are tent-shaped (equilateral) or square-tipped, with aspect ratios $\sim 1$. Since these 


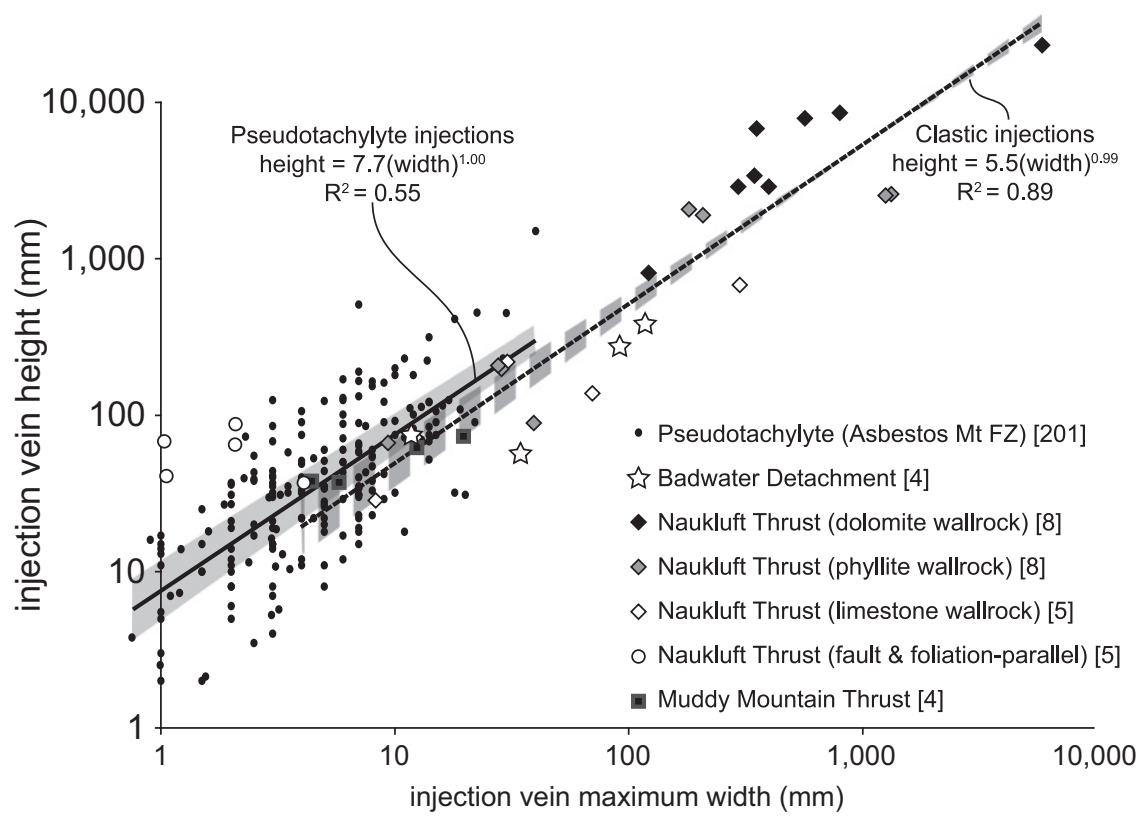

Fig. 4. Height and width of pseudotachylyte and granular injection veins. Pseudotachylyte injection veins (measured at Deep Canyon and La Quinta transects shown on Fig. 1, number of measurements for each fault given in brackets). Vertical streaks in data at small widths reflect measuring to the nearest millimeter. Power law regression shown in solid line $(n=201)$. Standard error in slope shown in gray around solid line. $R^{2}=0.55$. $P$-value $=7 \times 10^{-13}$. Clay gouge injections from the Badwater Detachment, Death Valley, California (white stars). Injections from the Naukluft Thrust, central Namibia are shown with diamond symbols and color indicates the lithology of the wall rock into which the fault gouge injected. White circles show fault-parallel injections which branch off the major fault-normal injections. These were not included in the regression. Black squares are gouge injections from the Muddy Mountain Thrust, southern Nevada. Dotted regression line calculated from all the granular injections except the ones shown in open circles $(n=29)$. Gray striped region defines error in slope $(\sigma=0.0665) . R^{2}=0.8881$ and $p$-value $=2 \times 10^{-13}$.

A

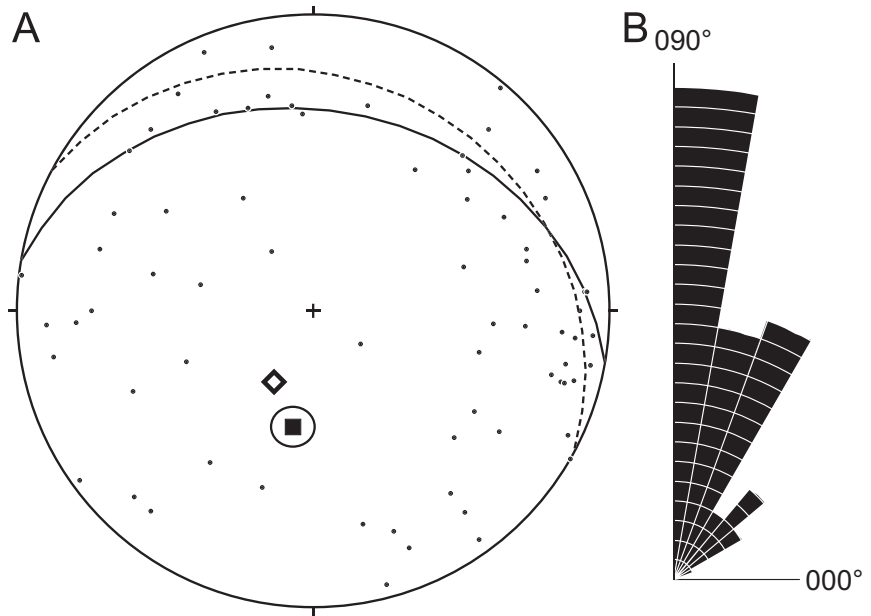

Fig. 5. (A) Orientations of fault and injection pseudotachylyte veins. Injection veins are steeply dipping, but there is no apparent pattern in strike orientation. Mean plane of fault pseudotachylyte veins (parallel to the local orientation of the Asbestos Mountain Fault), 280/33N, $n=65$ (solid great circle) and mean pole (black square with $95 \%$ confidence circle). Poles to injection veins, $n=71$ (small black dots) and best cylindrical fit (dotted great circle; pole shown in open diamond). (B) Rose diagram showing angle between fault vein and its own injection veins. $N=67$. Mean $=70 \pm 2^{\circ}$ (one standard error).

injections are approximately the same size and shape as the grain size of the host rocks (2-10 $\mathrm{mm}$ for quartz and feldspar crystals), they may form by mechanisms such as filling voids left by plucking of grains or by preferential melting of hydrous minerals as is observed in other pseudotachylyte faults (e.g. Spray, 1992).

The height of the pseudotachylyte injection veins is correlated with the width (Fig. 4). The mean ratio of width to height is $0.17 \pm 0.025$ (99\% confidence), and the slope of the best fit line in $\log$ space is $1.00 \pm 0.06$. Although the correlation coefficient $\left(R^{2}\right)$ of the data indicates that only $55 \%$ of the data variability is explained by the linear trend, the probability that the values are uncorrelated is $\ll 1\left(p\right.$-value $\left.=7 \times 10^{-31}\right)$. Data from both the Deep Canyon and La Quinta study sites (Fig. 1; transects A and B) are included in the analysis.

The measured injection veins occur on both sides of each fault vein, which are generally parallel to the overall orientation of the Asbestos Mountain fault. The injection veins have a broad distribution of strikes (Fig. 5A). When multiple injection veins were measured along the same fault vein, we observed that there were local clusters with similar orientation (within a few $\mathrm{cm}$ apart; Fig. 2D) but that along a single fault vein there was substantial variation. However, all the injections are at a high angle to their source fault veins $\left(70 \pm 2^{\circ}\right.$; Fig. 5B). This is the same as the apparent intersection angles measured by Di Toro et al. (2005) in 2D on the Gole Larghe fault.

Of the measured veins, two-thirds injected downward into the footwall of the slip surface and one-third injected upwards. There is no significant difference between the upward and downward directed injections in size, orientation, or angle to the source fault vein.

\section{Granular fault rock injections}

We measured injection veins of granular fault rock (gouge and breccia) in three shallow continental fault settings.

The Badwater Detachment, Death Valley, California is an active normal fault forming the eastern edge of Death Valley that has produced Holocene earthquakes that ruptured the surface (Hayman et al., 2003). We measured four upward-directed gouge injections along an exposure of the fault surface where the hanging wall consists of weakly consolidated alluvial fan material over chloritic schist of the footwall (thoroughly described by Cowan et al., 2003). The injections are straight-walled and the clayey gouge is strongly aligned, defining a U-shaped curve in foliation between the injection walls (Fig. 6A). 

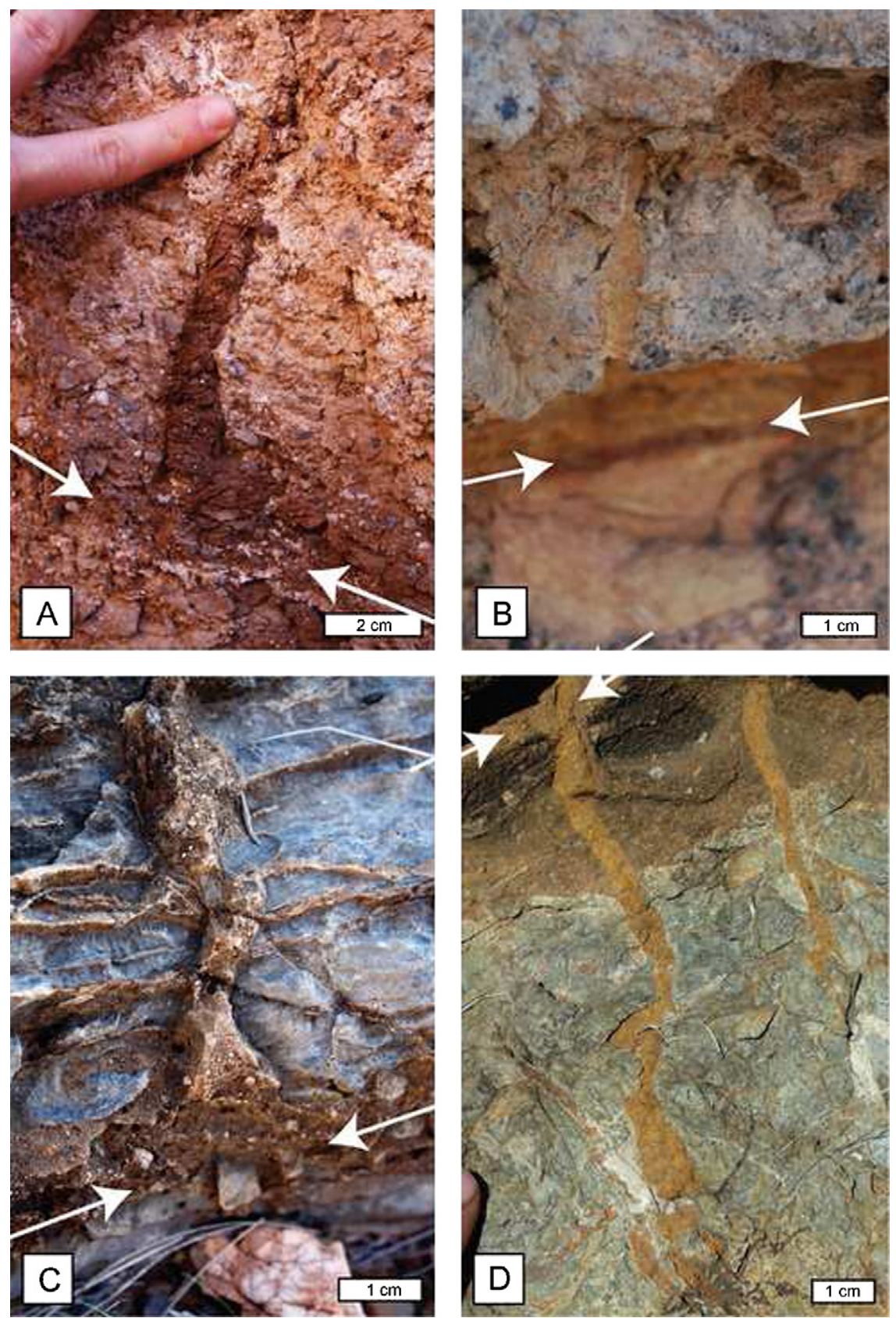

Fig. 6. Granular injection veins. (A) Injection of clay gouge cutting alluvium in the hanging wall of the Badwater Detachment, Death Valley, CA. White arrows indicate slip surface and source of injected gouge. Note convex-upward arcuate foliation in gouge recording drag along injection walls. (B) Fine-grained yellow cataclasite injection emanating from core of Muddy Mountain Thrust. The host rock is cemented dolomitic breccia (gray clasts are primary wall rock material). Fault core gouge has been eroded back about one meter (lower half of photo), leaving the projected hanging wall and injection in the foreground. (C) Dolomite gouge injection into limestone mylonite below the Naukluft Thrust. Primary injection (vertical) also shows subsidiary injections (horizontal) extending along mylonitic foliation (with distinctly lower width/length ratio). (D) Fine-grained dolomitic gouge injections (orange) across older fault rock (brown) and into phyllite wall rock (greenish gray) in the hanging wall of the Naukluft Thrust. (For interpretation of the references to color in this figure caption, the reader is referred to the web version of this article.)

The Muddy Mountain Thrust, exposed at Buffington Windows near Las Vegas, Nevada is a shallowly dipping Sevier-age continental thrust fault. The depth of activity of the fault is poorly constrained, but the thin-skinned thrust fault likely ruptured to the surface in the foreland basin (Brock and Engelder, 1977). Parts of the fault system have been reactivated in an extensional sense during the Cenozoic (Wernicke et al., 1985). At a slight map-scale bend in the fault surface, we measured four small injections of coherent gouge which extend upward into the hanging wall from a single $15 \mathrm{~mm}$-thick source layer within the thicker fault core, crosscutting adjacent layers of fine-grained fault rock (Fig. 6B).
The Naukluft Thrust is a low-angle foreland thrust fault last active ca. $500 \mathrm{Ma}$ in the Damara Belt of central Namibia (Viola et al., 2006). Injections of "gritty dolomite" ( $\sim 1-2 \mathrm{~mm}$ dolomite clast gouge) extend into the footwall and hanging wall rocks around the fault. These injections are generally tabular with tapering tips and can reach meters to $10 \mathrm{~s}$ meters in length (Makhubu, 2010; Rowe et al., submitted for publication; Sylvester, 2009). We measured injections ranging from very thin gouge injections to very large off-fault tabular gouge/breccia bodies. We differentiate the injections on the basis of host rock type (dolomite, limestone (Fig. 6C) and phyllite (Fig. 6D)). The local scale of injections is somewhat correlated to the host rock 
lithology, but there are only small, probably insignificant differences between the width/height ratios in the different host rocks. Similar to Muddy Mountain, the injections are most abundant near map-scale changes in the fault surface orientation.

The width is proportional to the length for the granular injections, and the aspect ratios of the composite dataset of $0.22 \pm 0.077$ are similar to those observed for the pseudotachylyte injections (Fig. 4). The slope of the line in log space is $0.99 \pm 0.067$, indicating that a constant aspect ratio explains the data well. For the fault-normal granular injections, the power-law fit is very good ( $p$-value $=$ $2 \times 10^{-13}$ ), and the pseudotachylyte best-fit overlaps with the range of the best fit power-law for the pseudotachylyte injections.

The power law regression of the granular injection data was calculated using only the injections that are at a high angle to the source fault and did not include their the subsidiary branches, which are sub-parallel to the source fault and follow a different relation (Figs. 4 and 6C). As the subsidiary branches are also parallel to local foliation in the surrounding rock (calc-mylonites and phyllites), the orientation may play a role in controlling the injection aspect ratios. These fault-parallel injection branches are of distinctly different shapes (aspect ratios $\sim 10^{-2}-10^{-3}$, Fig. 4). This observed anisotropy requires that greater injection opening occurred in the direction parallel to the fault.

\section{Interpretation of overpressure}

For a linear elastic opening-mode crack, the aspect ratio is a direct measure of the elastic strain imposed by the fracture on the wall rock (Lawn, 1993; Freund, 1998). However, the elastic limit of strain in most rocks is on the order of $10^{-2}$ (1\% Means,1976, p.240). The melt and gouge injections have relatively consistent aspect ratios of $\sim 0.2$. Reported width:length of igneous dikes are of the order from $10^{-3}$ to $10^{-4}$ (Rubin, 1995; Cruden and McCaffrey, 2002). The minimum aspect ratio of the injection veins we observed was $\sim 10^{-2}$. Clearly the fault-related injections are different than common igneous dikes. Therefore, the injection veins opened wide enough to exceed the elastic limit and should be partially accommodated by inelastic deformation of the wall rock.

\subsection{Net pressure estimates from injection veins}

The stress required to drive the inelastic deformation must be more than that to drive purely elastic strain at short timescales in a viscoelastic rock (Rubin, 1993), so we take the end-member fully elastic case as an upper limit. In a static fluid-filled elastic crack, the fluid pressure inside the crack is balanced by the normal stress on the crack from the wall rock (acting to close the crack, Fig. 3, based on Rubin, 1995). During crack propagation, the small region at the tip of the crack is at low pressure, and is pushed open by the elastic stress from the outward pressure of the fluid on the crack walls (but not yet filled with injecting fluid). The body of the crack is held open by the fluid pressure, which follows a gradient from the base of the injection to the negligible pressure in the vapor-filled crack tip. For the body of the crack, the net internal pressure required to hold it open $(\Delta P)$ is given by the following equation (Rubin, 1995):

$\Delta P=M \frac{w_{0}}{2 l}$

where $w_{0}$ is the maximum crack width, $l$ is the crack length, and $M$ is the stiffness $(\mu /(1-v)$ where $\mu$ is the shear modulus and $v$ is Poisson's ratio; see Table 1$)$.

We apply Eq. (1) to both the melt-filled and gouge-filled injection veins to calculate the net pressure required to produce the observed the injection vein aspect ratio if they are elastic cracks. The geometry expressed as $w_{0} / 2 l$ differs slightly from the symmetrical crack modeled by Rubin (1995), because the base of the injection vein can open freely along the fault vein (a free surface), which effectively reduces the resistance to opening by a factor of two. In this formulation, $\Delta P$ is the net pressure representing the sum of the fluid pressure and the wall rock stress state.

Using Eq. (1) and the values for Poisson's ratio and shear modulus reported in Table 1, we calculate that the upper limits on melt overpressures (for the purely elastic case) would range from $10^{8}$ to $10^{10} \mathrm{~Pa}$ (Fig. 7A). These numbers would be reduced by up to one order of magnitude if the wallrock to the injections was sufficiently damaged to reduce the bulk moduli. In the pseudotachylyte case, we have accounted for this by using rock properties appropriate to a foliated gneiss, but emphasize that these represent upper estimates.

We apply the same elastic crack formulation for the granular injections (Eq. (1)), but recalculate $M$ using appropriate values of the shear modulus and Poisson's ratio for the specific host rocks to the granular injections (Table 1 , Figs. 4 and 6). The $\Delta P$ estimates for granular injections clearly split into two groups: the carbonate and carbonate breccia-hosted injection veins that produce upper limits of $\Delta P \approx 10^{9}-10^{10} \mathrm{~Pa}$ and the phyllite and sediment-hosted injection veins that produce $\Delta P \approx 10^{7}-10^{9} \mathrm{~Pa}$

Table 1

Values used in injection vein pressure calculations.

\begin{tabular}{|c|c|c|c|}
\hline $\begin{array}{l}\text { Pseudotachylyte injection veins } \\
\text { Thermal diffusivity of silicate melt }(\kappa)\end{array}$ & $\begin{array}{l}10^{-6}-10^{-7} \mathrm{~m}^{2} / \mathrm{s} \\
2267 \times 10^{3} \mathrm{~kg} / \mathrm{m}^{3}\end{array}$ & Eriksson et al. (2003) & \\
\hline & & & \\
\hline Rock type & Relevant setting & Poisson's ratio $(v)$ & Shear modulus (Pa) \\
\hline Foliated gniess (density $\rho_{s}=2700 \mathrm{~kg} / \mathrm{m}^{3}$ ) & $\begin{array}{l}\text { Similar to foliated granodiorite of Asbestos } \\
\text { Mountain suite }\end{array}$ & 0.17 (Hakala et al., 2007) & $\begin{array}{l}2.4 \times 10^{10} \mathrm{~Pa} \text { (Hakala et al., } 2007 \text {, } \\
\text { measured parallel to foliation) }\end{array}$ \\
\hline $\begin{array}{l}\text { Granular injection veins } \\
\text { Rock type }\end{array}$ & Relevant setting & Poisson's ratio $(v)$ & Shear modulus (Pa) \\
\hline Limestone & $\begin{array}{l}\text { Local foot wall and host to some injections in the } \\
\text { Naukluft Thrust }\end{array}$ & 0.3 (Kulhawy, 1975) & $\begin{array}{l}2.64 \times 10^{10}(\text { Peselnick and } \\
\text { Outerbridge, 1961) }\end{array}$ \\
\hline Dolostone & $\begin{array}{l}\text { Local hanging wall and host to some injections in the } \\
\text { Naukluft Thrust }\end{array}$ & 0.28 (Kulhawy, 1975) & $2.8 \times 10^{10}$ (Agosta et al., 2007) \\
\hline Chlorite phyllite & $\begin{array}{l}\text { Local hanging wall and host to some injections in the } \\
\text { Naukluft Thrust }\end{array}$ & 0.2 (Nasseri et al., 2003) & $5.7 \times 10^{9}$ (Nasseri et al., 2003) \\
\hline Unconsolidated alluvial fan sediments & $\begin{array}{l}\text { Hanging wall and host to gouge injections in the } \\
\text { Badwater Detachment }\end{array}$ & 0.15 (Kulhawy, 1975) & $4.4 \times 10^{8}$ (Lin et al., 2000) \\
\hline Dolomitic Breccias (somewhat cohesive) & Hanging wall and host to some injections in the & 0.3 (Agosta et al., 2007) & $2.278 \times 10^{10}$ (Agosta et al., 2007) \\
\hline
\end{tabular}


A

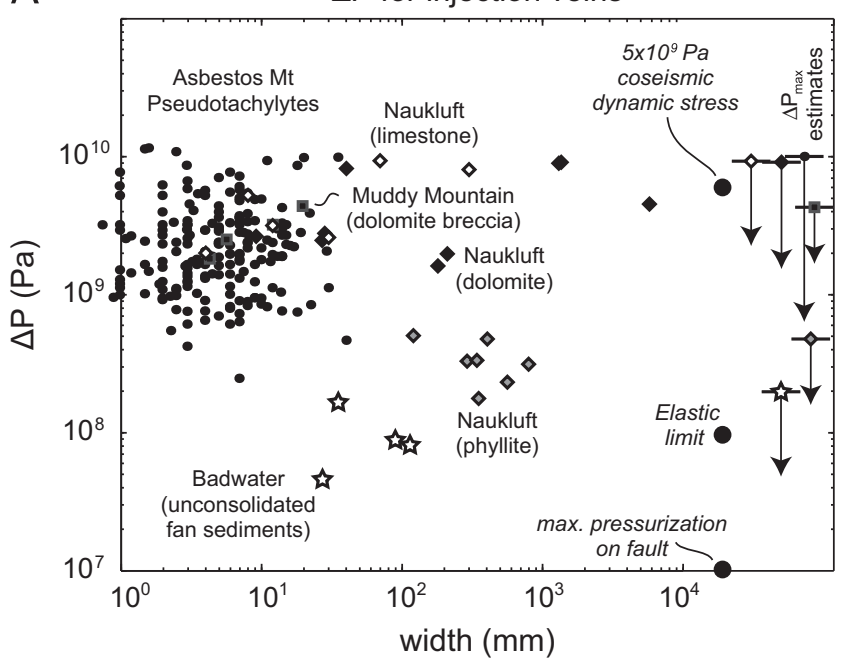

B

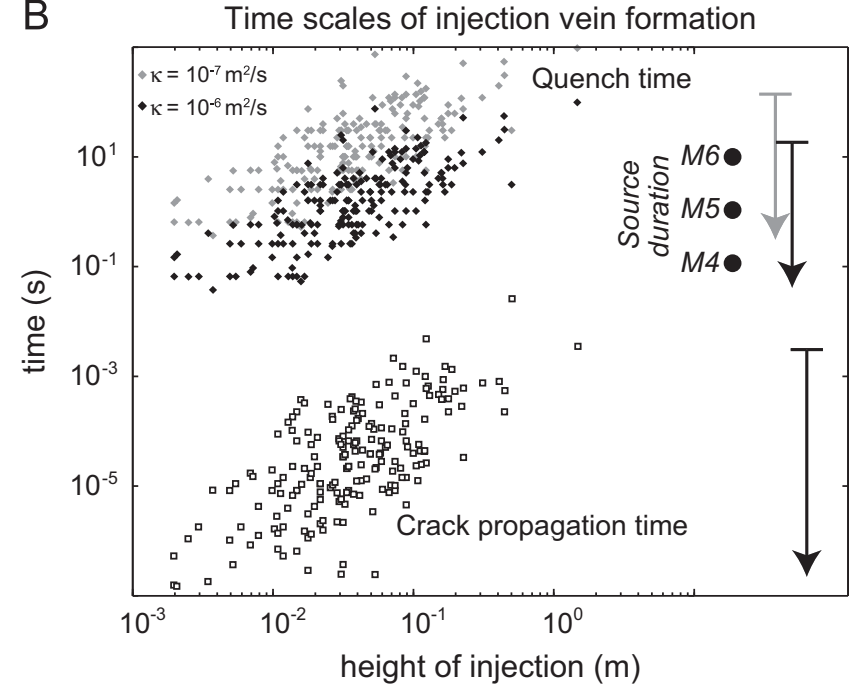

C Viscosity and solidus of wet melt

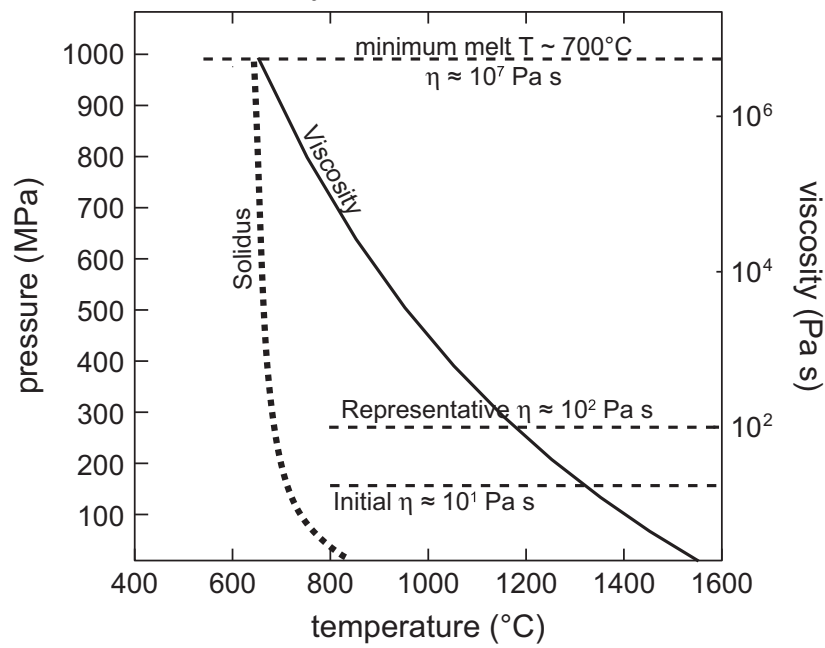

Fig. 7. (A) Calculated overpressure limits $(\Delta P)$ from pseudotachylyte and granular injections for the fully elastic case. Symbols are the same as those used in Fig. 4 . Asbestos Mountain fault zone pseudotachylytes (black dots, $n=201$, gray dot $=$ mean $=10^{9.6} \pm 0.02$ ). Granular injections from Naukluft Thrust (diamond symbols, coloured for host rock lithology: white=limestone, $n=5$; black=dolomite, $n=8$; gray=phyllite, $n=8$ ), the Muddy Mountain Thrust (squares, $n=4$ ) and Badwater Detachment (stars, $n=4$ ). Pressure limits from each population of injection veins indicated with arrows at right. Estimates of maximum fault surface pressurization, elastic limit of wall rock to pseudotachylyte veins, and coseismic dynamic stress (Reches and Dewers, 2005) shown in filled dots. (B) Calculated melt quench time and crack propagation time for the same measured pseudotachylyte injection veins plotted vs. injection vein height. Time is estimated for two different values of $\kappa\left(10^{-6} \mathrm{~m}^{2} / \mathrm{s}\right.$, black diamonds; $10^{-7} \mathrm{~m}^{2} / \mathrm{s}$, gray diamonds, Eriksson et al. (2003)). Crack propagation time shown in open squares. Range of time scales for quenching and crack propagation are indicated with arrows at right. Source duration for M4-M6 earthquakes shown in filled dots (Kanamori and Brodsky, 2004). For any given injection, quench time is $\geq 3$ orders of magnitude longer than the time required for the crack to propagate and similar to a moderate earthquake duration. (C) Solidus (dotted line) and viscosity-temperature (solid line) curves for composition of sample PC491 (Wenk et al., 2000) from granodiorites near transect B-B'. Solidus calculated using Thermocalc. Viscosity calculated using CONFLOW (Mastin and Ghiorso, 2000). Within the ranges of observed clast concentration ( $\ll 10 \%$ ) and a range of possible depths (conservatively $1-12$ km), there is no discernible effect of these factors on melt viscosity (all curves are superposed on the scale of this plot).

(Fig. 7A). Unsurprisingly, the difference between the estimates is largely controlled by the host-rock stiffness values we selecte$\mathrm{d}$ because the aspect ratio of all the injection veins is very similar.

The overpressure estimates from the injection vein aspect ratios using the elastic formulation represent an upper bound on the contribution of fluid overpressure to injection aspect ratio because the wall rock must have accommodated some deformation inelastically. The shear stress in the elastic regime is limited by the Coulomb failure criterion. For faults at $5 \mathrm{~km}$ depth, the lithostatic stress is $\sim 10^{8} \mathrm{~Pa}$ and the maximum shear stress is of the same order. Therefore, the observed driving pressure is on the order of the failure strength of rock and may be limited by these inelastic processes.
Distributed inelastic deformation must be responsible for the wall rock strain to accommodate the injections beyond the elastic limit. Bestmann et al. (2011) show examples of combined fracturing and plastic deformation at the tip of pseudotachylyte injection veins, and Wenk et al. (2011) show evidence of high-pressure shock twinning developed around pseudotachylytes. This damage requires stresses reaching the elastic limit. We observed no penetration of melt into grain boundaries or any other evidence of leakage from the fault surface melt reservoir except for into the injection veins, so we assume that the melt volume was preserved (Fig. 2). There is no evidence of macroscopic crystal plastic deformation of crystals cut by the pseudotachylyte veins (Fig. 2A, E). The foliation in the gneissic host rock is defined by elongate hornblende and biotite that could potentially have 
localized shear but would be difficult to quantify. Although the exact contribution of different mechanisms to accommodating the strain imposed on the wall rock by the injections can not be quantified in this study, we can estimate from laboratory observed elastic limits that $\sim 90 \%$ of the strain must have been inelastic damage at high strain rates, requiring stresses attaining the elastic limit.

In summary, the observed strains require extreme pressure conditions. We determine from the elastic limit of the wall rock that the injections may accommodate strains of up to 0.01 or more elastically, corresponding to pressures up to $\sim 10^{8} \mathrm{~Pa}$. The strain recorded in our aspect ratio measurements is one order of magnitude higher, requiring higher stresses to drive strain beyond the elastic limit, regardless of the mechanism of deformation. An extreme upper limit on pressure $\left(\sim 10^{8}-10^{10} \mathrm{~Pa}\right)$ is bounded by the (theoretical) fully elastic case for our aspect ratio measurements. These values are consistent with the minimum pressure estimates by Wenk et al. (2011) who reported pressures of $1-2 \times 10^{8}$ Pa based on shock twinning in quartz found along the same faults. In the next section, we explore possible explanations for these high pressures.

\subsection{How much pressure can be generated on-fault?}

Melt formation is itself a process that causes pressurization; the density of melt is less than the density of the parent rock, and this decrease in density causes escalation of the pressure in a confined system. This mechanism has been mentioned in the literature but not analyzed in detail (Swanson, 1992; Di Toro and Pennacchioni, 2004; Nielsen et al., 2008). Similarly, as fluid (silicate melt or aqueous pore fluid in the granular case) is heated, expansion also occurs. This thermal pressurization has received more attention in the literature (Mishima et al., 2006; Rice, 2006; Noda and Shimamoto, 2005; Lachenbruch and Sass, 1980; Mase and Smith, 1987; Bizzarri and Cocco, 2006; Sulem et al., 2004). Granular fluidization may also be achieved by acoustic fluidization (Melosh, 1996). Any of these mechanisms would require extreme pressurization to explain the aspect ratios of the fault rock injections.

The incremental increase in pressure in the fault zone with initial width $w_{0}$ due to expansion of a fluid is

$\Delta P=M \frac{\Delta w}{w_{0}} \frac{w_{0}}{L}$

where $\Delta w / w_{0}$ is the volumetric expansion and the elastic stiffness $M=\mu /(1-v)$.

Table 2

Rock sample composition used for density and viscosity calculations. Composition from Wenk et al.'s (2000) sample PC491 (Granodiorite from bedrock adjacent to Martinez Mountain landslide, near transect B (Fig. 2, see text) and normative (anhydrous) mineralogy calculated using Hollocher (2011).

\begin{tabular}{lcclc}
\hline Oxide & $\begin{array}{l}\text { Wt\% } \\
\text { (host rock) }\end{array}$ & $\begin{array}{l}\text { Wt\% } \\
\text { (pseudotachylyte) }\end{array}$ & Mineral & $\begin{array}{l}\text { Normative } \\
\text { volume \% }\end{array}$ \\
\hline $\mathrm{SiO}_{2}$ & 58.4 & 54.2 & Quartz & 16.7 \\
$\mathrm{TiO}_{2}$ & 0.9 & 1.1 & Anorthite & 24.52 \\
$\mathrm{Al}_{2} \mathrm{O}_{3}$ & 16.1 & 16.5 & Diopside & 2.897 \\
$\mathrm{Fe}_{2} \mathrm{O}_{3}$ & 2.2 & 2.2 & Hypersthene & 7.165 \\
$\mathrm{FeO}$ & 3.0 & 3.4 & Albite & 28.57 \\
$\mathrm{MnO}$ & 0.1 & 0.1 & Orthoclase & 17.3 \\
$\mathrm{MgO}$ & 2.5 & 2.8 & Apatite & 0.427 \\
$\mathrm{CaO}$ & 5.7 & 7.0 & Ilmenite & 1.061 \\
$\mathrm{Na} 2 \mathrm{O}$ & 3.0 & 3.4 & Magnetite & 1.365 \\
$\mathrm{~K}_{2} \mathrm{O}$ & 2.1 & 2.5 & & \\
$\mathrm{P}_{2} \mathrm{O}_{5}$ & 0.2 & 0.2 & & 100 \\
$\mathrm{Total}$ & 94.2 & 93.4 & & \\
\hline
\end{tabular}

To proceed, we need constraints on the source vein geometry. For pseudotachylytes, Wenk et al. (2000) reported aspect ratios of $1-2 \times 10^{-1}$ for all pseudotachylyte bodies in the area (combining fault veins and injection veins). Kirkpatrick and Shipton (2009) and Di Toro and Pennacchioni (2005) report aspect ratios from $10^{-2}$ to $10^{-4}$ for similar pseudotachylyte fault veins in the Sierra Nevada, and Gole Larghe, respectively. As pseudotachylyte spreads out along a fault surface from the melt-source asperities, and approximately half the original pseudotachylyte melt is squeezed off fault into injections (Di Toro and Pennacchioni, 2005), the smaller values can be considered to be lower limits on primary melt source aspect ratios. It is more difficult to constrain the source fault vein geometry in the case of the granular injections, where remobilization obscures the limits of individual deformed fault rock layers. We therefore limit our estimates to the pseudotachylyte case for which individual event surfaces can be measured.

One potential source of additional expansion for the pseudotachylytes is the exsolution of volatile phases from the melt once it has formed, or the pressurization of aqueous phases already present along the fault before earthquake slip. However, exsolution is considered unlikely due to the remaining high water content in the pseudotachylyte melt (Table 2), and the fact that supercritical water is expected to be completely miscible in the melt at these conditions (Liebscher, 2010).

For melting, the expansion is approximately $10 \%$ and therefore for $M \approx 10^{10} \mathrm{~Pa}$ and the widest aspect source regions, $\Delta P \approx 10^{7} \mathrm{~Pa}$. This is an order of magnitude below the minimum estimate of pressure recorded by the wall rock injection veins (at least $10^{8} \mathrm{~Pa}$ ). However, given the estimated depth of fault activity ( $\sim 3-10 \mathrm{~km}$, Wenk et al., 2000), the magnitude of fault vein pressurization may approach the lithostatic stress on the fault.

\section{Dynamic underpressure in the wall rock: explaining $\Delta P$}

A pseudotachylyte injection vein that formed early during the initial stages of an earthquake may be completely quenched before the slip on the distal portions of the fault have ceased. Dynamic as well as static effects could influence the injection vein aspect ratios. Dynamic tension pulses can be extremely large, as evidenced by the abundant damage in fault zones even in the absence of injection veins (estimated at up to $5 \times 10^{9} \mathrm{~Pa}$, Reches and Dewers, 2005). This large tension may contribute toward the net overpressure which determines the injection vein aspect ratios. Therefore, we compare three timescales: the timescale of earthquake slip on the fault, the timescale of crack growth to create injection veins, and the timescale of injection solidification to assess the possibility of dynamic conditions influencing injection aspect ratios (Fig. 7B). We again limit our analysis to the pseudotachylyte injections where estimating the timescale of melt quenching can constrain the time for injection solidification.

In order for dynamic underpressure to be considered a viable mechanism for widening the injection veins, both the total propagation time of the injection crack and the time for the melt to stiffen to preserve the crack (for the pseudotachylyte case) need to be shorter than or equal to the duration of coseismic stress field. The dynamic stress field associated with an earthquake is at most the duration of rupture. The Asbestos Mountain fault trace is at most 10's of kilometers long and it is unlikely that the fault hosted an earthquake larger than a magnitude 6 . The maximum rupture duration is therefore of the order of $10 \mathrm{~s}$ (Kanamori and Brodsky, 2004). Locally the duration of the slip pulse is at least an order of magnitude less than the total rupture time (Kanamori and Anderson, 1975). In order for dynamic underpressure to be a viable explanation both the propagation 
and quench times need to be less than $\sim 1-10 \mathrm{~s}$, the time scale of dynamic stress conditions influencing the fault during a M6 earthquake. For smaller events or stresses confined to the rupture tip, the timescale would be reduced by several orders of magnitude (Fig. 7B). Given the uncertainties in this analysis, we focus on this extreme upper bound of the dynamic stress time in order to constrain the possible injection generation processes.

\subsection{Propagation time of the injection crack}

The relative durations of the crack propagation time and quench time are also important. If crack propagation was slow (i.e., propagation time was large) compared to quench time, then the aspect ratios of the cracks might be controlled by crack propagation. If quench time is much larger (slower) than crack propagation time, then the net pressure in the melt is the control on observed injection aspect ratios.

If the quench time is longer than the crack growth time, cracks would open, fill with melt, and quench while the width/length ratio reflects the balance between the ambient stress from the wall rock and the pressure in the melt. We calculate each of these timescales for the pseudotachylyte injections. Modelling the injection vein intrusion process as limited by a Poseuille flow in the thin crack with the fluid pressure field coupled to the elastic stresses results in a propagation velocity $U$ of approximately

$U \approx \frac{1}{3 \eta} \frac{\Delta P^{3}}{M^{2}} l$

where $\eta$ is the fluid viscosity (Rubin, 1995). Then solving for the crack opening time by substituting $U=l / t_{\text {crack }}$ results in

$t_{\text {crack }}=\frac{3 \eta M^{2}}{\Delta P^{3}}$

Application of Eq. (4) (Fig. 7B) requires calculation of the melt viscosity. We estimated viscosity as a function of temperature using the compilation of laboratory rheological constraints implemented by Conflow (Mastin and Ghiorso, 2000). We used XRF analysis reported by Wenk et al. (2000) of pseudotachylyte cutting granodiorite most closely matching the typical host rock at the sites of our study transects (Sample PC491; Table 2) to determine the melt composition. Water has a significant influence on melt viscosity. Although we have no independent constraint on whether free water was in the fault at the time of melting, the host granodiorite includes hornblende and biotite, and the loss on ignition (LOI; equivalent to water content) during preparation of the host rock for XRF analysis was 5.8\%. Mineral-bound water became available when the fault surface reached the temperature of biotite melting $\left(700-720^{\circ} \mathrm{C}\right.$ at $\sim 1 \mathrm{GPa}$; Peterson and Newton, 1989). As discussed above, at these conditions, any water present is in supercritical phase and completely miscible in silicate melt (Liebscher, 2010). We therefore used the LOI as a proxy for water content and calculated the viscosity of the melt assuming $5 \%$ dissolved water.

We explored the variations in viscosity due to overburden pressure between 1 and $12 \mathrm{~km}$ depth and the variation in clast composition from $1 \%$ to $10 \%$. The model is insensitive to either depth or clast population within these ranges, and all the calculated viscosity-temperature curves plot on top of one another within that space (Fig. 7C). We assumed that the initial melt temperature was high, consistent with other studies of similar pseudotachylytes $\left(1450^{\circ} \mathrm{C}\right.$; Di Toro and Pennacchioni, 2004), and therefore the initial viscosity was about 10 Pa s (Fig. 7C). The vein may be considered quenched when it cools to the solidus, which was calculated using Thermocalc ( $\sim 700^{\circ} \mathrm{C} ; \eta \sim 10^{7} \mathrm{~Pa} \mathrm{~s}$ ). As Eq. (4) is less sensitive to viscosity than to the other parameters, and the crack propagation must have occurred early when viscosity was still low, we use a representative viscosity during the cooling period $\left(10^{2}\right.$ Pa s; Fig. $\left.7 \mathrm{C}\right)$. Since the average viscosity over the quench period is higher than the initial viscosity (during crack propagation), our crack propagation times are upper estimates.

\subsection{Quench time}

The time required to completely quench an injection to temperatures below the glassing temperature when cooling by conduction of heat into the wall rock as a function of the maximum injection width $w$ is

$t_{\text {quench }} \approx \frac{(w / 2)^{2}}{\kappa}$

where $\kappa$ is the thermal conductivity (Turcotte and Schubert, 2002). Using a reasonable approximation of $\kappa\left(\sim 10^{-6}-10^{-7} \mathrm{~m}^{2} / \mathrm{s}\right.$; Eriksson et al., 2003), the total glassing time for our population of vein measurements is $10^{-1}-10^{3} \mathrm{~s}$ (similar to the cooling time for pseudotachylyte fault veins calculated by Dixon and Dixon, 1989; Sibson, 1975) (filled dots; Fig. 7B). However, this is an upper estimate on the time required to sufficiently stiffen the injection vein such that the aspect ratio is preserved. The actual proportion of quenched melt required to stabilize the vein aspect ratio may vary with individual vein geometries; $50 \%$ of maximum width is used here for an estimate of quench time to achieve stabilization (diamonds, Fig. 7B). For thermal diffusivity $\kappa=10^{-6} \mathrm{~m}^{2} / \mathrm{s}$ and assuming half-width quenching, the quench time is $0.1-10 \mathrm{~s}$, well in excess of the crack growth time and similar to the duration of dynamic stresses around the fault.

For the very largest veins considered here, early in their history, some advective cooling may have shortened the effective quench time. Therefore, the relevant quench times are shorter than the estimates from Eq. (5). Conversely, viscous dissipation may be important for injections with half widths $\leq 1-3 \mathrm{~mm}$ if the melt overpressure is $10^{7}-10^{8}$ (Rubin, 1995, Eqs. (16) and (17)). In this case, the quench time may be slightly greater than the estimates shown in Fig. 7B.

\subsection{Timescale of injection formation}

For each injection in our data set, half-width quench time clearly exceeds the crack propagation time by 3-6 orders of magnitude (Fig. 7B). Therefore, we can reject the possibility that injection length was limited by crack propagation rate during melt flow. For all possible ranges in vein formation time (bounded by crack propagation time and quench time, Fig. 7B), the Reynolds number is small ( $<10^{-3}$ for $95 \%$ of the injection veins) so inertial effects are negligible. For the measured injections, the half-width quench times (0.1-10 s) are comparable to, or less than, the maximum duration of slip for a moderate $(M \sim 6)$ earthquake if we use the higher thermal diffusivity $\left(10^{-6} \mathrm{~m}^{2} / \mathrm{s}\right)$. As the implied overpressure cannot be generated by fluid expansion alone, wall rock tension is required. The orientations of the pseudotachylyte injection veins with respect to the fault veins are also consistent with the dynamic stress field. Although strikes vary, the angle between the fault vein and injection veins is nearly always above $70^{\circ}$, the angle predicted if the injection cracks form in the dynamic stress field around a propagating rupture front (Di Toro et al., 2005; Griffith et al., 2009).

\section{Application to granular fault rock injections}

A similar set of constraints must also apply to the granular fault rock injections. However, compared to the quenching of pseudotachylyte melt, the jamming process of granular flows is poorly understood (Corwin et al., 2005). Granular injections form 
when gouge flows into fractures in response to a transient pressure spike. As the pressure drops, the grains interlock and prevent the gouge from flowing back out of the crack. Therefore, the aspect ratio of the injection veins may be locked in during the highest peak net pressures experienced by the fault rock. If this is true, then the identical aspect ratios measured in the pseudotachylyte and granular injection veins suggest that both were locked in at peak overpressure conditions.

We have estimated the overpressure generated on a fault surface during earthquake slip by any mechanism (such as frictional melt expansion or fluid pressurization) at $\sim 10^{7} \mathrm{~Pa}$. All of the injection veins, however, require overpressures greater than $10^{8} \mathrm{~Pa}$. As the average injection vein aspect ratio is an order of magnitude greater than the elastic strain limit, the overpressures recorded by the injection veins are much greater than the fluid pressures generated on-fault.

This apparently paradoxical observation appears to be best explained by invoking dynamic tension parallel to the fault, which can reach $\sim 5 \times 10^{9} \mathrm{~Pa}$ (Reches and Dewers, 2005). The anisotropy of the dynamic tensile pulse is consistent with the injections showing higher aspect ratios than the source faults and the fault-perpendicular branching injections. This explanation is satisfactory for the granular injections, where granular locking would freeze the primary aspect ratios upon injection, and the coincidence of both injection sets showing the same aspect ratios may suggest that the same dynamic tensile pulse is preserved in both cases.

\section{Implications for coseismic weakening}

The estimated fault surface pressurization $\left(\sim 10^{7} \mathrm{~Pa}\right)$ approaches the lithostatic pressure at 3-5 km depth, the representative depth of faulting of the majority of faults we studied. If developed along a fault during an earthquake, even if only along limited segments of a fault, it would have a major weakening effect during slip. Our observations suggest that melt pockets are found in isolated lenses along the fault surfaces, probably representing some smaller fraction of the total rupture surface area, are consistent with descriptions of pseudotachylyte-bearing faults from other areas (Kirkpatrick and Shipton, 2009; Griffith et al., 2010). Previous studies have shown that frictional melting begins at asperities, the effectively strongest points on the fault surface, where the heat production is highest (Swanson, 1992; O'Hara, 2005; Rice, 2006). In addition, variations in the thickness or normal stress of the slip zone could result in a spatially variable onset of melting for uniform heat production (Kirkpatrick and Shipton, 2009). Localized melting on these points, now represented by isolated lenses of pseudotachylyte in fault veins, record the replacement of the strongest points along the rupture surface with overpressured melt pockets, thereby controlling the stress drop on the fault (Kirkpatrick et al., 2012).

Similarly, fluidization (by thermal pressurization or acoustic fluidization, for example) in saturated gouges is expected to be most effective at asperities (either geometric or frictional strong points on the fault surface). In some of our study sites, injections were spatially associated with map-scale fault bends (Makhubu, 2010; Sylvester, 2009). Thus, we infer that this deformation documents the transformation of asperities (strong points) into pressurized zones (weak points) along a seismically slipping fault.

In the case that thermal pressurization facilitated the granular fluidization, we can compare to the results from experiments in the laboratory for lower bounds on peak temperature and pressure (limited by laboratory constraints on confinement and stress). Even so, catastrophic weakening is observed, with normal stress/shear stress ratios dropping from initial values from $\sim 0.6$ to $0.1-0.2$ (see compilation by Di Toro et al., 2011; Reches and Lockner, 2010). This is corroborated by temperature measurements across faults soon after earthquakes (Kano et al., 2006). Our estimates of overpressure imply negligibly small normal stress/shear stress ratios develop coseismically, and provide further evidence for near total weakening of the slipping surface.

\section{Conclusions}

Both pseudotachylyte and granular injection veins from fault surfaces are wide compared to intrusive dikes in igneous systems. The aspect ratios average $\sim 0.2$. The predicted injection aspect ratio from the constraint of the elastic limit is $\sim 0.01$, so the net pressure forming the injections must have achieved the elastic limit. The pressurization of the fault surface is unlikely to exceed $10^{7} \mathrm{~Pa}$, which is enough to approach lithostatic load on the fault, but insufficient to explain the injection aspect ratios. In order to make the very wide injections, we suggest that dynamic tension during earthquake slip is the best explanation. Pseudotachylyte and gouge injection veins have the same aspect ratios, implying both form coseismically. This is the first report that gouge injections (of this aspect ratio) form convincing evidence for paleo-earthquakes.

\section{Acknowledgements}

Allan Rubin and an anonymous reviewer are thanked for very detailed comments which greatly improved this manuscript. Field collaborations: Tim Sherry and Lia Lajoie at the Asbestos Mountain Fault, Bandile Makhubu, Ben Mapani, and Åke Fagereng at the Naukluft Thrust, and Nicholas van der Elst, Heather Savage, and Lia Lajoie at the Muddy Mountain Thrust. Tom Mitchell and W. Ashley Griffith for helpful discussions. Boyd Deep Canyon Desert Research Center (University of California) and Al Muth for accommodations, helpful discussions, tips, tricks, and lizard facts. C. Rowe was supported by NSF MARGINS Fellowship (Award 0840977) and J. Kirkpatrick was supported by NSF EAR (Award 0948740).

\section{References}

Agosta, F., Prasad, M., Aydin, A., 2007. Physical properties of carbonate fault rocks, Fucino Basin (Central Italy): implications for fault seal in platform carbonates. Geofluids 7, 19-32, http://dx.doi.org/10.1111/j.1468-8123.2006.00158.x.

Axen, G.J., Fletcher, J.M., 1998. Late Miocene-Pleistocene extensional faulting, northern Gulf of California, Mexico and Salton Trough, California. Int. Geol. Rev. 40, 217-244.

Bestmann, M., Pennacchioni, G., Nielsen, S., Goken, M., de Wall, H., 2011. Deformation and ultrafine dynamic recrystallization of quartz in pseudotachylyte-bearing brittle faults: a matter of a few seconds. J. Struct. Geol. 33, 169-186.

Bizzarri, A., Cocco, M., 2006. A thermal pressurization model for the spontaneous dynamic rupture propagation on a three-dimensional fault: 1 . Methodological approach. J. Geophys. Res. 111 http://dx.doi.org/10.1029/2005JB003862.

Brantut, N., Schubnel, A., Corvisier, J., Sarout, J., 2010. Thermochemical pressurization of faults during seismic slip. J. Geophys. Res. 115 http://dx.doi.org/ 10.1029/2009JB006533.

Brock, W.G., Engelder, T., 1977. Deformation associated with the movement of the Muddy Mountain overthrust in the Buffington window, southeastern Nevada. Geol. Soc. Am. Bull. 88, 1667-1677.

Corwin, E.I., Jaeger, H.M., Nagel, S.R., 2005. Structural signature of jamming in granular media. Nature 435 http://dx.doi.org/10.1038/nature03698.

Cowan, D.S., 1999. Do faults preserve a record of seismic slip? A field geologist's opinion. J. Struct. Geol. 21, 995-1001.

Cowan, D.S., Cladouhos, T.T., Morgan, J.K., 2003. Structural geology and kinematic history of rocks formed along low-angle faults, Death Valley, California. Geol. Soc. Am. Bull. 115, 1230-1248. 
Cruden, A., McCaffrey, K., 2002. Different scaling laws for sills, laccoliths and plutons: mechanical thresholds on roof lifting and floor depression. In: Breitkreuz, C. Mock, A. Petford, N. (Eds.), First International Workshop: Physical Geology of Subvolcanic Systems - Laccoliths, Sills and Dykes, vol. 20. Wissenschaftliche Mitteilung Instute fur Geologie Technische Universitat Bergakademie Freiberg, pp. 15-17.

Cruden, A., McCaffrey, K., 2006. Dimensional scaling relationships of tabular igneous intrusions and their implications for a size depth and compositionally dependent spectrum of emplacement processes in the crust. EOS Trans. AGU 87. (Abstract V12B-06)

Di Toro, G., Han, R., Hirose, T., Paola, N.D., Nielsen, S., Mizoguchi, K., Ferri, F., Cocco, M., Shimamoto, T., 2011. Fault lubrication during earthquakes. Nature 471, 494-498, http://dx.doi.org/10.1038/nature09838.

Di Toro, G., Nielsen, S., Pennacchioni, G., 2005. Earthquake rupture dynamics frozen in exhumed ancient faults. Nature 446, 1009-1012.

Di Toro, G., Pennacchioni, G., 2004. Superheated friction-induced melts in zoned pseudotachylytes within the Adamello tonalites (Italian Southern Alps). J. Struct. Geol. 26, 1783-1801.

Di Toro, G., Pennacchioni, G., 2005. Fault plane processes and mesoscopic structure of a strong-type seismogenic fault in tonalites (Adamello batholith, Southern Alps). Tectonophysics 402, 55-80.

Dixon, J.E., Dixon, T.H., 1989. Vesicles, amygdules, and similar structures in faultgenerated pseudotachylytes: comment. Lithos 23, 224-225.

Eriksson, R., Hayashi, M., Seetharaman, S., 2003. Thermal diffusivity measurements of liquid silicate melts. Int. J. Thermophys. 24, 785-797.

Erskine, B.G., Wenk, H.R., 1985. Evidence for Late Cretaceous crustal thinning in the Santa Rosa mylonite zone, southern California. Geology 13, 274-277.

Ferri, F., Di Toro, G., Hirose, T., Shimamoto, T., 2010. Evidence of thermal pressurization in high-velocity friction experiments on smectite-rich gouges. Terra Nova 22, 347-353, http://dx.doi.org/10.1111/j.1365-3121.2010.00955.x.

Freund, L.B., 1998. Dynamic Fracture Mechanics, Cambridge Monographs on Mechanics and Applied Mathematics. Cambridge University Press.

George, P.G., Dokka, R.K., 1994. Major Late Cregaceous cooling events in the eastern Peninsular Ranges, California, and their implications for Cordilleran tectonics. Geol. Soc. Am. Bull. 106, 903-914, http://dx.doi.org/10.1130/00167606.

Griffith, W.A., Nielsen, S., Di Toro, G., Smith, S.A.F., 2010. Rough faults, distributed weakening, and off fault deformation. J. Geophys. Res. 115 http://dx.doi.org/ 10.1029/2009JB006925

Griffith, W.A., Rosakis, A., Pollard, D.D., Ko, C.W., 2009. Dynamic rupture experiments elucidate tensile crack development during propagating earthquake ruptures. Geology 37, 795-798, http://dx.doi.org/10.1130/G30064A.1.

Grocott, J., 1981. Fracture geometry of pseudotachylyte generation zones: a study of shear fractures formed during seismic events. J. Struct. Geol. 3, 169-178.

Gudmundsson, A., 1995. Infrastructure and mechanics of volcanic systems in Iceland. J. Volcanol. Geotherm. Res. 64, 1-22.

Hakala, M., Kuula, H., Hudson, J.A., 2007. Estimating the transversely isotropic elastic intact rock properties for in situ stress measurement data reduction: a case study of the Olkiluoto mica gneiss, Finland. Int. J. Rock Mech. Mining Sci. $44,14-46$.

Hayman, N.W., Knott, J.R., Cowan, D.S., Nemser, E., Sarna-Wojcicki, A.M., 2003. Quaternary low-angle slip on detachment faults in Death Valley California. Geology 31, 343-346.

Hollocher, K., 2011. CIPW Norm Calculation Excel Spreadsheet. Downloaded from Union College website on 4/21/11.

Jaeger, H.M., Nagel, S.R., 1996. Granular solids, liquids and gases. Rev. Modern Phys. 68, 1259-1273.

Kanamori, H., Anderson, D.L., 1975. Theoretical basis of some empirical relations in seismology. Bull. Seismol. Soc. Am. 65, 1073-1095.

Kanamori, H., Brodsky, E.E., 2004. The physics of earthquakes. Rep. Prog. Phys. 67, 1429-1496.

Kano, Y., Fujio, R., Ito, H., Yanagidani, T., Nakao, S., Ma, K.F., 2006. Heat signature on the Chelungpu Fault associated with the 1999 Chi-Chi, Taiwan earthquake. Geophys. Res. Lett. 33 http://dx.doi.org/10.1029/2006GL026733.

Kirkpatrick, J.D., Dobson, K.J., Mark, D.F., Shipton, Z.K., Stuart, F.M. Coseismic stress drop variability from exhumed faults. Geophys. Res. Lett., 2012. http://dx.doi. org/10.1029/2011JB008846.

Kirkpatrick, J.D., Shipton, Z.K., 2009. Geologic evidence for multiple slip weakening mechanisms during seismic slip in crystalline rock. J. Geophys. Res. $114 \mathrm{http}: / /$ dx.doi.org/10.1029/2008JB006037.

Kulhawy, F.H., 1975. Stress deformation properties of rock and rock discontinuities. Eng. Geol. 9, 350-375.

Lachenbruch, A.H., Sass, J.H., 1980. Heat flow and energetics of the San Andreas fault zone. J. Geophys. Res. 85, 6097-6112.

Lawn, B., 1993. Fracture of Brittle Solids. Cambridge Solid State Science Series, second edition. Cambridge University Press.

Liebscher, A., 2010. Aqueous fluids at elevated pressure and temperature. Geofluids 10, 3-19, http://dx doi.org/10.1111/j.1468-8123.2010.00293 x.

Lin, A., 2011. Seismic slip recorded by fluidized ultracataclastic veins formed in a coseismic shear zone during the $2008 \mathrm{M}_{W} 7.9$ Wenchuan earthquake. Geology 39, 547-550, http://dx.doi.org/10.1130/G32065.1.

Lin, S.Y., Lin, P.S., Luo, H.S., Juang, C.H., 2000. Shear modulus and damping ratio characteristics of gravelly deposits. Can. Geotech. J. 37, 638-651.

Macaudiere, J., Brown, W.L., Ohnnstetter, D., 1985. Microcrystalline textures resulting from rapid crystallization in a pseudotachylite melt in a metaanorthosite. Contrib. Mineral. Petrol. 89, 39-51.
Makhubu, B., 2010. Geometry and Off-fault Deformation of a km-Scale Fault Irregularity. BSc Honours Thesis in Geological Sciences. University of Cape Town.

Mase, C.W., Smith, L., 1987. Effects of frictional heating on the thermal, hydrologic, and mechanical response of a fault. J. Geophys. Res. 92, 6249-6272.

Mastin, L.G., Ghiorso, M.S., 2000. A Numerical Program for Steady-State Flow of Magma-gas Mixtures Through Vertical Eruptive Conduits. Open File Report. U.S. Geological Survey 00-209.

Means, W.D., 1976. Stress and Strain: Basic Concepts of Continuum Mechanics for Geologists, 4th edition Springer-Verlag.

Melosh, H.J., 1996. Dynamical weakening of faults by acoustic fluidization. Nature 379, 601-606.

Mishima, T., Hirono, T., Soh, W., Song, S.R., 2006. Thermal history estimation of the Taiwan Chelungpu fault using rock-magnetic methods. Geophys. Res. Lett. 33 http://dx.doi.org/10.1029/2006GL028088.

Mitsui, Y., Hirahara, K., 2010. Coseismic thermal pressurization can notably prolong earthquake recurrence intervals on weak rate and state friction faults: numerical experiments using different constitutive equations. J. Geophys. Res. 114 http://dx.doi.org/10.1029/2008JB006220.

Nasseri, M.H.B., Rao, K.S., Ramamurthy, T., 2003. Anisotropic strength and deformational behavior of Himalayan schists. Int. J. Rock Mechan. Mining Sci. 40, 3-23.

Nielsen, S., Di Toro, G., Hirose, T., Shimamoto, T., 2008. Frictional melt and seismic slip. J. Geophys. Res. 113 http://dx.doi.org/10.1029/2007JB005122.

Noda, H., Shimamoto, T., 2005. Thermal pressurization and slip-weakening distance of a fault: an example of the Hanaore fault, Southwest Japan. Bull. Seismol. Soc. Am. 95, 1224-1233. http://dx.doi.org/10.1785/0120040089.

O'Hara, K., 2005. Evaluation of asperity-scale temperature effects during seismic slip. J. Struct. Geol. 27, 1892-1898.

Otsuki, K., Monzawa, N., Nagase, T., 2003. Fluidization and melting of fault gouge during seismic slip: identification in the Nojima fault zone and implications for focal earthquake mechanisms. J. Geophys. Res. 108, 18, http://dx.doi.org/ 10/1029/2001JB001711, 2003.

Passchier, C.W., 1982. Pseudotachylyte and the development of ultramylonite bands in the Saint-Barthélemy Massif, French Pyrenees. J. Struct. Geol. 4, 69-79.

Peselnick, L., Outerbridge, W.F., 1961. Internal friction in shear and shear modulus of Solenhofen Limestone over a frequency range of $10^{7}$ cycles per second. J. Geophys. Res. 66, 581-588.

Peterson, J.W., Newton, R.C., 1989. Reversed experiments on biotite-quartzfeldspar melting in the system KMASH: implications for crustal anatexis. J. Geol. 97, 465-485.

Philpotts, A.R., 1964. Origin of pseudotachylytes. Am. J. Sci. 262, 1008-1035.

Reches, Z., Dewers, T.A., 2005. Gouge formation by dynamic pulverization. Earth Planet. Sci. Lett. 235, 361-374.

Reches, Z., Lockner, D.A., 2010. Fault weakening and earthquake instability by powder lubrication. Nature 467, 452-455, http://dx.doi.org/10.1038/ nature09348.

Rice, J.R., 2006. Heating and weakening of faults during earthquake slip. J. Geophys. Res. 111, B05311.

Rowe, C.D., Fagereng, A., Miller, J.A., Mapani, B. Signature of coseismic decarbonation in dolomite fault rocks of the Naukluft Thrust, Namibia. Earth Planet. Sci. Lett., Accepted.

Rowe, C.D., Moore, J.C., Meneghini, F., McKiernan, A.W., 2005. Large-scale pseudotachylytes and fluidized cataclasites from an ancient subduction thrust fault. Geology 33.

Rubin, A.M., 1993. Dikes vs. diapirs in viscoelastic rock. Earth Planet. Sci. Lett. 117, 653-670.

Rubin, A.M., 1995. Propagation of magma-filled cracks. Ann. Rev. Earth Planet. Sci. 23, 287-336.

Sharp, R.V., 1968. The San Andreas fault system and contrasting pre-San Andreas structures in the Peninsular Ranges of southern California. In: Dickinson, W.R., Grantz, A. (Eds.), Geologic Problems of the San Andreas Fault System. Stanford University, pp. 292-293.

Sharp, R.V., 1979. Some characteristics of the Eastern Peninsular Ranges Mylonite Zone. In: Proceedings of the Conference on Analysis of Actual Fault Zones in Bedrock Open File Report 79, pp. 258-267.

Sibson, R.H., 1975. Generation of pseudotachylyte by ancient seismic faulting. Geophys. J. R. Astron. Soc. 43, 775-794.

Simpson, C., 1984. Borrego Springs-Santa Rosa mylonite zone: a late Cretaceous west-directed thrust in southern California. Geology 12, 8-11.

Spray, J.G., 1992. A physical basis for the frictional melting of some rock-forming minerals. Tectonophysics 204, 205-221.

Sulem, J., Vardoulakis, I., Ouffroukh, H., Boulon, M., Hans, J., 2004. Experimental characterization of the thermo-poro-mechanical properties of the Aegion Fault gouge. C. R. Geosci. 336, 455-466.

Swanson, M.T., 1989. Sidewall ripouts in strike-slip faults. J. Struct. Geol. 11, 933-948.

Swanson, M.T. 1992. Fault structure, wear mechanisms and rupture processes in pseudotachylyte generation. Tectonophysics 204, 223-242.

Sylvester, F.Y.G., 2009. The Size, Shape and Style of a Continental Detachment: Fault Geometries and Brittle-Ductile Behaviour of the Naukluft Thrust Namibia. B.Sc. honours. University of Cape Town.

Tanikawa, W., Shimamoto, T., 2009. Frictional and transport properties of the Chelungpu fault from shallow borehole data and their correlation with seismic behavior during the 1999 Chi-Chi earthquake. J. Geophys. Res. 114 http://dx.d oi.org/10.1029/2008JB005750. 
Todd, V.R., Erskine, B.G., Morton, D.M., 1988. Metamorphic and tectonic evolution of the northern Peninsular Ranges Batholith, southern California. In: Ernst, W.G. (Ed.), Metamorphism and Crustal Evolution of the Western United States: Rubey Volume VII. Prentice Hall, Englewood Cliffs, New Jersey, pp. 894-937. Turcotte, D.L., Schubert, G., 2002. Geodynamics. Cambridge University Press ISBN 0-521-66186-2.

Ujiie, K., Yamaguchi, A., Kimura, G., Toh, S., 2007. Fluidization of granular materia in a subduction thrust at seismogenic depths. Earth Planet. Sci. Lett. 259, 307-318.

Viola, G., Mancktelow, N.S., Miller, J.A., 2006. Cyclic frictional-viscous slip oscillations along the base of an advancing nappe complex: insights into brittleductile nappe emplacement mechanisms from the Naukluft Nappe Complex, central Namibia. Tectonics 25 http://dx.doi.org/10.1029/2005TC001939.
Webb, S., Courtial, P., 1996. Compressibility of melts in the $\mathrm{CaO}-\mathrm{Al}_{2} \mathrm{O}_{3}-\mathrm{SiO}_{2}$ system. Geochim. Cosmochim. Acta 60, 75-86.

Wenk, H.R., Janssen, C., Kenkmann, T., Dresen, G., 2011. Mechanical twinning in quartz: shock experiments, impact, pseudotachylytes and fault breccias. Tectonophyiscs 510, 69-79.

Wenk, H.R., Johnson, L.R., Ratschbacher, L., 2000. Pseudotachylytes in the Eastern Peninsular Ranges of California. Tectonophysics 321, 253-277.

Wernicke, B., Walker, J.D., Beaufait, M.S., 1985. Structural discordance between Neogene detachments and frontal Sevier thrusts, central Mormon Mountains, southern Nevada. Tectonics 4, 213-246, http://dx.doi.org/10.1029/ TC004i002p00213.

Wibberly, C.A.J., 2002. Hydraulic diffusivity of fault gouge zones and implications for thermal pressurization during seismic slip. Earth Planets Space 54, 1153-1171. 